\section{Revisiting Chinese Labour NGOs: Some Grounds for Hope?}

\section{Ivan Franceschini}

In the past decade, scholars have put forward several scathing criticisms of Chinese labour NGOs that go well beyond the usual concerns about the lack of transparency and internal democracy. Still, many things have changed in the past few years and now the time may be ripe for a reassessment of the role of these organizations.
In the past decade scholars have put forward several scathing criticisms of Chinese labour NGOs that go well beyond the usual concerns about the lack of transparency and internal democracy. Some have criticised them for being nothing less than 'anti-solidarity machines' that, by putting too much emphasis on an individualistic view of rights, hinder the development of a labour movement among Chinese migrant workers; others have noted how these organisations are also working for the benefit of the party-state, which they assist by minimizing social conflict and orienting reforms in a way acceptable to the authorities. In a previous article, I myself joined the ranks of the critics, highlighting how Chinese labour NGOs suffer from a substantial lack of 'social capital', due not only to their strained relations with the party-state, but also to the considerable difficulties they face in gaining workers' trust. Although these criticisms could be deemed ungenerous given the difficulties that these NGOs face under the constraints of the Chinese political system, they were grounded in years of observation and participation in the daily operations of these organizations. Still, the

Wuijun, a worker and NGO volunteer, was detained for over a year in 2013. PC: HKCTU

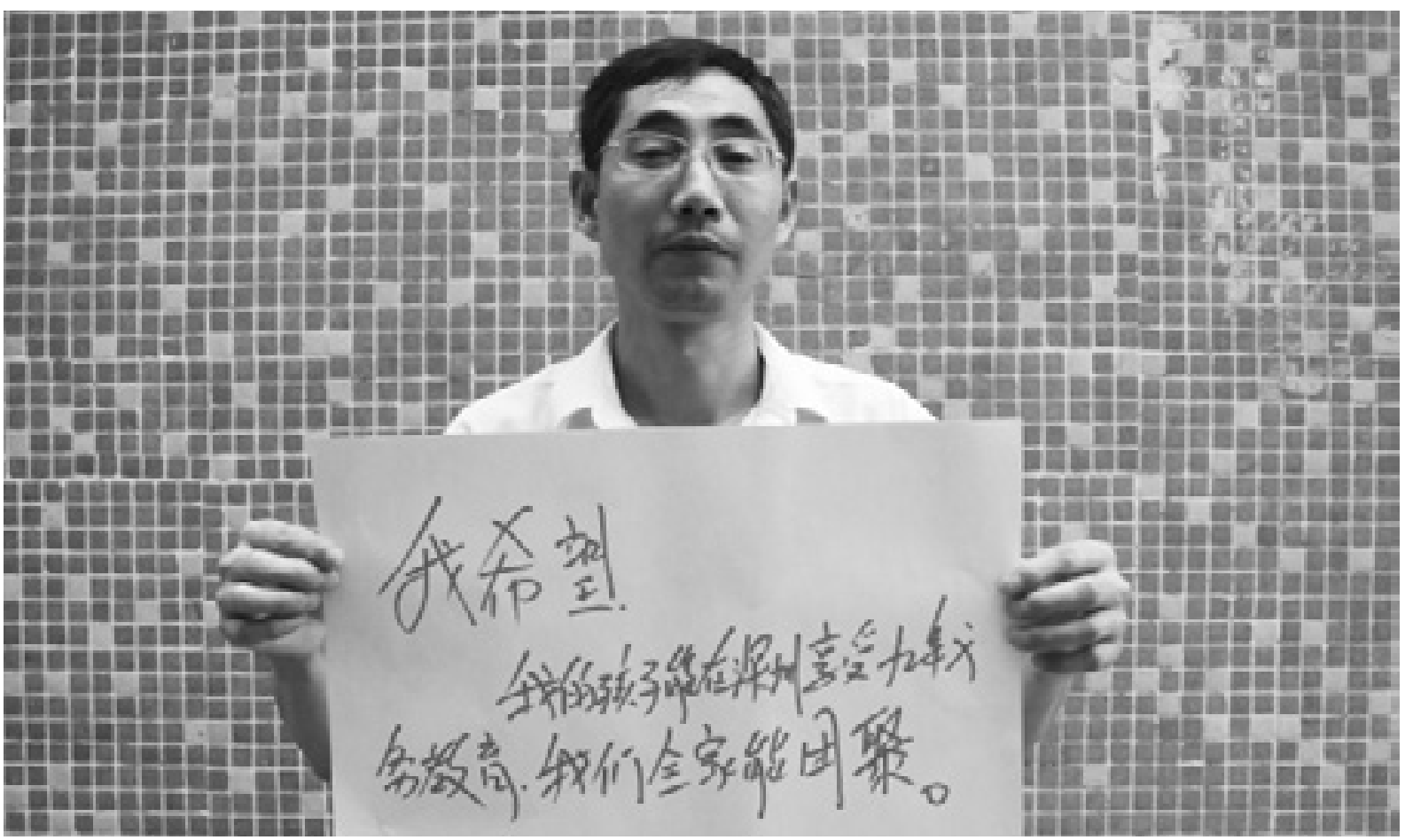


time may be ripe for a reassessment of Chinese labour NGOs.

\section{Less Incorporation and More Repression}

Since their appearance in China in the mid-nineties, in spite of their minimal size and lack of coordination, labour NGOs have always had to face the suspicions of the party-state. Already in 2009, an internal document by the Guangdong Politics and Law Committee of the Communist Party categorized labour NGOs as civic agents who intensify labour conflicts, carry out covert investigations of factories, and receive funding from overseas entities to intervene in the 'contradictions among the people' (renmin neibu maodun), endangering social stability, the security of the state, and even the international image of the country. More recently, in February 2015, Li Yufu, Vice-President of the official union, stigmatised labour NGOs for their connections with foreign donors. Noting that 'the trends in the field of industrial relations are complex and intricate, and labour contradictions have already entered a phase of intensification and multiplication,' he denounced that 'the interferences by hostile foreign forces are getting stronger, in the futile attempt to use industrial relations to break through.' According to Li, these forces 'resort to some illegal "weiquan" labour organisations and individuals to vie with the unions for workers, and so doing they break the solidarity of the working class and the unity of the unions.'

As Jude Howell has noted, what we have witnessed in recent years is a paradoxical development in which the partystate has pursued the 'incorporation' of some NGOs for welfaristic purposes, while simultaneously repressing others. If the attempts at incorporating Chinese labour NGOs seem to have been a feature more of the latest years of the $\mathrm{Hu}$ and
Wen administration than of the current leadership, repression has indeed intensified, reaching a climax in last December. In the past few years, Chinese labour NGOs have been increasingly exposed to a wide array of threats and intimidations by the state security apparatus. This repression has taken many forms. Besides the usually non-confrontational praxis of inviting labour activists to 'have a cup of tea' (he cha), public and state security officers have often put pressure on landlords to repeatedly evict NGOs from their premises and have not refrained from liaising with other branches of the state (family planning offices, tax offices, social security offices, schools, etc.) to harass not only the activists, but also their families. In the worst cases, this repression took the semblance of an authentic police persecution. It happened in 2013 to Wu Guijun, a worker and NGO volunteer who was detained for over a year for joining a strike against the relocation of the company he worked in, and it is happening today to Zeng Feiyang, Meng Han, Zhu Xiaomei and He Xiaobo, the four labour activists formally arrested in early January (Zhu was later released on bail).

Worth noting is that, while this repression has led some labour NGOs to shut down, many others have simply changed name and revised their strategies. A closer look reveals that, in comparison to 2012 , today in China there are more labour NGOs, but they are smaller in size. Even more important is the fact that the new organisations that have emerged in the past couple of years were mostly founded by activists of NGOs that had fallen victim to state repression. Although they now work independently from each other, these activists maintain friendly relations with their former colleagues, a development that in the long run is likely to foster solidarity and trust among organisations, laying the foundation for a tighter and more effective network that may even be able to exert some influence at a policy level. From this point of view, 
there are signs that indicate that atomisation not necessarily is a signal of impending annihilation.

\section{Labour NGOs and Migrant Workers' Struggles}

Another significant development concerns the way labour NGOs deal with migrant workers' struggles. While until a few years ago, labour NGOs steered clear of collective disputes and politically sensitive cases-a modus operandi which attracted much criticism from the international academic community-recently some organisations have displayed a remarkable willingness to engage with labour strikes and protests, effectively promoting collective bargaining (jiti tanpan) as a tool to solve labour disputes. This can be seen not only in many ordinary disputes related to unpaid employers' social insurance contributions, severance pay, overtime, and housing contribution schemes, but also in various high-profile cases that involved several hundreds if not thousands of workers, such as the Yue Yuan strike in Dongguan in 2014 and the struggle of the Lide employees in Guangzhou in 2014 and 2015. That such events remain politically sensitive is proven by the severity of the consequences for the activists involved. In 2014 an NGO worker involved in the Yue Yuan strike was detained for a month after trying to convince the workers to elect their representatives to bargain collectively with the management, and today Zeng Feiyang and his colleagues are paying dearly for their involvement in the Lide campaign, which is being played up by the Chinese state media as a case in which greedy activists neglected the interests of the workers in order to achieve money and fame.

Duan Yi, a prominent labour lawyer based in Shenzhen, recently argued that labour NGOs are transitioning from 'service-oriented organisations' (fuwuxing) and 'rights protection-oriented organi- sations' (weiquanxing) to 'labour movement organisations' (gongyunxing). Yet, such a conclusion may be premature and even dangerous. It is premature because most labour NGOs still focus on providing services to migrant workers and, at most, deal with individual disputes of very limited social and political impact, such as cases related to occupational health and safety. It is dangerous because the term 'labour movement' evokes spectres of worker upheaval, which have been haunting the Chinese leadership since the early eighties. According to my latest interviews, very few labour activists identify their organisations with the 'labour movement' label. As an NGO leader in Shenzhen told me:

Some scholars say that we are 'labour movement organisations'. I don't agree completely. I think that it would be more appropriate to define us as 'comprehensive organisations' (zonghexing). Why? Because our organisation carries out service work, rights-protection work, and even some work with strikes simultaneously... Sure, you can also talk about labour movement, the expression is not bad, but in my opinion it is not complete, it doesn't cover all facets. Moreover, this expression easily catches the attention of the government. If you talk about labour movement, the Party, who started to establish itself exactly through the labour movement... gets alarmed. Why? Because this is the way in which they came to power. For this reason, I prefer to use the term 'comprehensive' to define us and the other labour NGOs that engage with collective bargaining.

[Interview, September 2015]

Lexical quibbles aside, it is undeniable that in recent years some labour NGOs have started to experiment with new strategies to engage more closely with migrant workers and have proved themselves willing to face the wrath of the authorities in order to push the boundaries 
of the political discourse and praxis. Although these organisations are still far from being 'independent trade unions', they are becoming more responsive to the real needs of migrant workers. In this respect, it is significant that the input for this push toward collective disputes and collective bargaining has come not only from foreign donors (which nevertheless played a fundamental role in this shift), but also from the workers themselves. In this regard, the experience of a Southern labour NGO established in 2012 with the aim of carrying out cultural and recreational activities for female migrant workers is particularly interesting. As one of the leaders, herself an injured migrant worker, told me:

At the end of 2012, many controversies between labour and capital arose in the factories around us and these female workers came to our centre to ask for information... During the winter, we organised a meeting during which we asked them to vote on what kind of activities best fit their interests. They chose trainings in law, collective bargaining and communication techniques. Their choices were completely different from what we expected! On this basis, since the end of 2012, we have rearranged our work, starting to deal with the rights of female workers and with collective bargaining. [Interview, April 2015]

\section{Some Grounds for Hope?}

In all likelihood, it was the very fact that labour NGOs were increasingly willing to deal with collective disputes, engage more closely with the workers, and promote a confrontational model of collective bargaining very different from the official narrative of 'collective negotiation' (jiti xieshang), that triggered the latest, unprecedented, crackdown against them. Organised groups that didn't work as 'anti-solidarity machines', but actually promoted worker solidarity were highly menacing to the party-state and the official union, especially in light of the current slowdown of the Chinese economy. For this reason, Zeng Feiyang and his colleagues, who were at the forefront of this new trend, were made into a public example for all labour activists in China and abroad. Still, although the situation in China today is very grim, even in this bleak hour there may still be good reason to look at the future of Chinese labour NGOs with some optimism. As described above, even in a context of further atomisation of these organisations, activists from NGOs targeted by state repression are breaking off to establish their own groups, a development that in the future may foster the emergence of a stronger solidarity network. Moreover, some activists are also adopting 'guerrilla' tactics, working on an individual basis and bringing aid in areas where no labour NGO is present. In other words, the recent repression may have caused a temporary setback for labour NGOs, but in spite of all difficulties, activists are already finding new ways to adapt to the shifting circumstances. It remains to be seen how far the party-state is willing to go to fight this wave and whether the migrant workers will remain silent or will finally start to speak up for those who have been risking everything to fight for their rights.

\section{Ivan Franceschini}

Ivan Franceschini is a Marie Curie Fellow at Ca' Foscari University of Venice and at the Australian Centre on China in the World working on a project on Chinese labour in global perspective. From 2006 to 2015 , he lived in China, where he worked as a journalist and as a consultant in the field of development cooperation. His research interests focus on Chinese labour and civil society. 